\title{
Van? Nincs? Hogyan van, ha nincs? Esszé a japán tehetségpedagógiáról
}

\author{
GORDON GYőri JÁNOS
}

Eötvös Loránd Tudományegyetem, Pedagógiai és Pszichológiai Kar

\begin{abstract}
Ez a tanulmány úgy mutatja be a formális, fóáramú oktatást Japánban, mint amelyet egyszerre jellemeznek erös egyenlöség- és versenyelvü vonások. Az egyenlöségelvüségböl is következik, hogy a "tehetség/tehetséges” kifejezéseknek megfelelö kifejezést is nehéz a japán nyelvben találni. Kulturális értékekben, az oktatásra vonatkozó mai ideológiai irányokban érhetó tetten annak a magyarázata, hogy a japán társadalom számos tagja - tanárok, diákok, szülök és mások - miért legalábbis ambivalensek a tehetségpedagógiával szemben. Mindazonáltal egy sor tehetséggondozó oktatási program zajlik Japánban. A jelen tanulmány a japán tehetséggondozás konceptuális hátterét és mindennapi gyakorlatát mutatja be.
\end{abstract}

Kulcsszavak: egyenlöségelvüség az oktatásban, tehetséggondozás, Japán

Jelen sorok írója 1996-ban járt először Japánban, akkor mint házastárs, akinek a felesége (Dr. Fülöp Márta) a Japán Alapítvány ösztöndíjával egy évig a japán társadalom versengéssel kapcsolatos jellemzőit kutatta kulturális szociálpszichológiai szempontokból. Ez az egy év éppen alkalmasnak látszott arra, hogy én magam is helyszíni kutatásokat folytassak az engem akkoriban leginkább érdeklő pedagógiai kérdések egyikéről, a tehetséggondozás kérdéséről. A téma annál is inkább érdekelt, mert abban az évben a doktori dolgozatomon dolgoztam, amelynek témája ugyancsak a tehetséges gyerekek pedagógiája volt - igaz, egészen más szempontokból: az intellektuális területeken tehetséges tanulók gondolkodási készségfejlesztésének elmélete és gyakorlata állt a munkám középpontjában, nem pedig a nemzeti tehetséggondozó programok vagy az iskolai tehetséggondozás mindennapi gyakorlata vagy hasonlók. Mégis, arra gondoltam, ha már itt vagyok Japánban, felgöngyölítem magamnak, hogy itt miként is zajlik a tehetséggondozás. Még azt is terveztem, hogy feltáró kutatásom eredményeit egy nagy jelentőségü magyar nyelvü tanulmányban összegzem majd, amelynek hatása - úgy gondoltam - nyilvánvalóan hatalmas lesz odahaza, hiszen mindannyiunk okulására lesz módom majd megmutatni a világ oktatásban és gazdaságban legsikeresebb országa- inak egyikéről, hogyan is kell a tehetséggondozást tényleg nagyon hatékonyan folytatni. Gondoltam: másképp hogyan is müködhetne a japán oktatás és gazdaság olyan hatékonyan, hogyan is lehetne e szigetország mindkét téren a világ élvonalában?

Nagyívű célom elérése érdekében először természetesen extenzív szakirodalmi kutatásba kezdtem. Heteken keresztül fésültem át minden lehetséges elérhető anyagot, de erőfeszítéseim teljes kudarcba fulladtak. Lényegében egy sort sem találtam a témáról, vagy ha valamit, akkor legfeljebb olyan általános leírásokat, amelyek a tehetséges tanulók fejlesztéséról mint a speciális pedagógia egy ágáról szóltak, de semmit nem mondtak arról, hogy mindez Japánban konkrétan, nemzeti szinten, az iskolák keretében pontosan hogyan is zajlik. Bár meglepődtem ezen az eredményen, nem estem kétségbe, ugyanis arra gondoltam, hogy így jár az, aki megfelelő nyelvismeret híján csak az angol nyelvü szakirodalmat tudja feltárni, a helyi, japán nyelvű szakirodalmat nem.

Úgyhogy gondoltam, nincs más lehetőségem, mint az, hogy megkérdezek a témáról olyan helyi szakembereket, akiknek megfelelően széles körủ rálátása lehet egy ilyen témára. Így is tettem. Ám a korábbiaknál is meglepőbb módon bárkit kérdeztem a pedagógiai tudományok területéről, mindenki egyönte- 
Van? Nincs? Hogyan van, ha nincs? Esszé a japán tehetségpedagógiáról

tűen azt állította, hogy Japánban nincs, nem létezik olyan, hogy tehetséges gyerekek pedagógiája. A téma olyannyira nem létezik és így kutathatatlan, hogy még csak megfelelő szó sincs a japán nyelvben a tehetségre, hiába is kérdezem az angol 'gifted' vagy 'talented' megfelelőjét.

Mindez azonban már valóban nem hagyott nyugodni. Egyrészt a nyelv- és a megfelelő helyismeret - az ország múltjának, kultúrájának, jelenének, oktatási jellemzőinek megfelelő mélységű ismerete - hiányában el kellett fogadnom, amit a japán szakemberek állítottak. Másrészt nem tudtam megszabadulni attól a gondolattól, hogy az lehetetlen, hogy egy olyan fejlettségű országban, mint Japán, nincs tehetségpedagógiai stratégia, nincsenek a tehetséges tanulókat segítő oktatási alrendszerek, valamint hogy az iskolákban nincsenek a tehetséges tanulók fejlesztése érdekében alkalmazott speciális módszerek.

Ezért pusztán spekulatív módszerekkel - de szakmailag megalapozott és szisztematikusan alkalmazott spekulációk alapján - megpróbáltam megérteni, hogy mik azok az elemek a japán oktatásügyben, amelyeket ugyan a helyi szakemberek és a hétköznap emberei sem neveznek tehetséggondozásnak, a mi fogalmainkkal azonban mégis annak tekinthetők. Később ezekről különféle összefüggésben, de általában a tehetséggondozás kontextusában elhelyezve írtam is a Japánból való hazatérésemet követő magyar nyelvű publikációimban. Például a japán iskolai klubrendszerről, a nemzetközileg is páratlanul szelektív felső középiskolai rendszerről, valamint az árnyékoktatás tehetséggondozásként is tekinthető változatairól (Sumida, 2013; Gordon Győri, 1998, 2006). Ugyanezen publikációkban általában igyekeztem kulturális kontextusban is elhelyezni, miért is zajlik sub rosa a tehetséggondozás Japánban.

Azonban még jó időnek kellett eltelnie ahhoz, hogy az 1990-es évek második felétől szórványosan születő japán publikációkból, tehát a japán oktatásügy saját, belső szempontjainak megismerése által lépésről lépésre igazolva láthassam, hogy tulajdonképpen szakmailag egészen jól spekuláltam. Más sza- vakkal: sikerült jól összeillesztenem egy olyan oktatásügyi részrendszer részjellemzőit, amelyről maga a rendszer azt állította, hogy nincs is, és amelyről lényegében mai napig tabu beszélni (ld. pl. Ibata-Arens, 2012).

A továbbiakban először azt foglalom öszsze, hogy a tehetséges tanulók pedagógiájával foglalkozó, mai napig is nagyon kis számú japán szakember milyen jellemzők mentén írja le a japán tehetséggondozás jellemzőit már ha egyáltalán mégis csak beszélhetünk ilyenekről -, illetőleg a tanulmány végén azt taglalom, miért is olyan bonyolult a tehetséggondozás kérdése azokban a társadalmi/kulturális kontextusokban, amelyekben erős szerepe van az oktatási egyenlőség eszméjének.

\section{Tehetségpedagógia a mai Japán oktatásügyben}

\section{Nyelvi bonyodalmak}

Valóban, mint arra a tehetségpedagógia kérdéseivel foglalkozó japán szakemberek közül többen is kitérnek, a japán nyelvben nehezen található bármi olyan kifejezés, amely megfelelően azonosítható lenne a mi tehetség fogalmunkkal, illetve az angol nyelvben használt 'gifted' és 'talented' fogalmaival. Amint azt nyelvi elemzésében Sumida (2013) és Matsumura (2016) is bemutatja, a japán sainou azért nemigen feleltethető meg az angol gifted-nek, mert míg az utóbbiban erősebb az öröklöttség elvének nyelvi konnotációja, a japán megfelelő inkább a környezeti tényezők erőfeszítéseinek köszönhető tehetségfogalmat fejez ki. Sumida hasonlóképp megfeleltethetetlennek látja a tensai vagy az eisai fogalmait az angol nyelvi megnevezéseknek. Ugyancsak nem egyeztethető megfelelő pontossággal a nyugati nyelvek fogalmi rendszerével a japán gakuryoku megnevezés, amely nagyjából a tanulók intellektuális területeken azonosítható képességeire, potenciáljára és egyben manifeszt-teljesítményére is utal, de valójában nem pontosan rögzített jelentéssel (Matsumura, 2016), minthogy nem tisztázott például az, hogy beleértendők-e motivációs és attitüdinális elemek is. Nyilvánva- 
ló, hogy e sok nyelvi bizonytalanság egyben episztemológiai bizonytalanság is, vagyis a nyugati értelemben vett tehetség fogalmának a hiányával, illetve annak másként való megkonstruáltságával áll kapcsolatban. Márpedig episztemológiai értelemben is hiányzó tehetségfogalomra nyilvánvalóan nehéz - valószínủleg lehetetlen is - világosan artikulált tehetségpedagógiát építeni.

\section{Történeti háttér}

Tehetségpedagógiai szempontból a japán oktatás történetében legalább négy periódus különíthető el: a Meiji restauráció előtti korszak, a Meiji restauráció periódusa a 2. világháború végéig számítva, a 2. világháború utáni korszak, illetőleg a 2000-es évekkel kezdő korszak.

A Meiji restaurációt megelőző, feudális Japánban az oktatás legkidolgozottabb formáját a szamurájok képzése jelentette. Ez lényege szerint nemcsak a kultúra széleskörű átadását jelentette, hanem az oktatás magasan individualizált formáját is, tekintve, hogy a szamurájok képzésében sok szempontból tekintetbe vették azt, hogy a mindenki által elsajátítandó alapok mellett kinek-kinek milyen érdeklődésére, képességirányára lehet építeni a képzését. Minthogy a mai Japánban is az individuális oktatás a tehetségpedagógiai tevékenység leginkább elfogadott iránya, az mondható, hogy a tehetségpedagógiai mai alapjai a szigetország feudális múltjáig nyúlik vissza. Természetesen jelentős különbség azonban az, hogy míg a Meiji korszakot megelőzően ez a képzési forma csak a messzemenő előnyöket élvező társadalmi kisebbséghez tartozó gyerekek privilégiuma volt - ritka kivétellel -, addig ma a tehetséges tanulók individuális oktatása egy évszázados hagyományokkal rendelkező tömegoktatás keretében valósul meg.

A Meiji korszak tehetségpedagógiai szempontból azért különösen érdekes, mert ekkor a japán kormányzat egy olyanféle kettős célt igyekezett egyszerre megvalósítani, amely látszólag megoldhatatlan ellentmondásokat rejtett magában: a) a világ legjobb oktatási színvonalú oktatásügyét megteremteni - a világ legerősebb gazdaságának (honvédelmének) megteremtése érdekében - úgy, hogy b) ez a lehető legmagasabb színvonalú oktatás a lakosság egészére, mindenkire kiterjedő tömegoktatás legyen. E kettős célrendszerben nemigen lett volna értelmezhető egy széles körü „elitista” tehetséggondozás az oktatásügyben (legalábbis a közoktatási szinten nem; hiszen ugyanakkor nem lehet megfeledkezni az e korszakban megteremtődő császári egyetemi rendszer tudományos szempontokból elit jellegéről). Kisebb tehetségpedagógiai alrendszerek még így is kialakultak a 2. világháborúig tartó időszakban, de ezek jelentősége nem volt túl nagy. Vagyis az oktatás nemzetközi összehasonlításban tekintve elitté emelésének nemzeti szintű programja a nemzeten belüli oktatás erős homogenitásával kapcsolódott össze (megint csak a közoktatásról beszélve).

A 2. világháborút követő korszak alapvető jellemzője megint csak az egalitárius szemlélet dominanciája jellemezte politikai, ideológiai és társadalomfejlesztési okokból egyaránt, többek között a társadalmi harmónia jegyében és érdekében. A korszakot a tehetségpedagógia elvi lehetőségének elutasítása jellemezte mind politikai/oktatáspolitikai szinteken, mind pedig a társadalmi közvélekedésben és közvéleményben, az oktatási egyenlőség nevében (West, 2016). A későbbiekben azonban éppen arra fogok rávilágítani, hogy e felszín alatt vagy mögött hogyan épült ki és bizonyos mértékig virágzott a tehetséges gyerekek speciális pedagógiája is.

A tehetségpedagógia szempontjából bekövetkező fontos szemléletváltás és immár a pedagógiai gyakorlatban is bekövetkező változások az 1990-es évektől kezdődő japán gazdasági stagflációval, a világgazdaság és a regionális gazdaság és politika mélyreható változásaival függ össze, mindenekelőtt Kína és részben India e periódusra tehető megerősödésével. Mindezek ugyanis Japánt egy újabb pedagógiai paradoxon megoldásának feladata elé állította: hogyan lehet megőrizni az oktatás évtizedek óta igazolhatóan nemzetközileg kiemelkedő, nemzeti szinten más országok- 
Van? Nincs? Hogyan van, ha nincs? Esszé a japán tehetségpedagógiáról

hoz képest egyenletesen magas színvonalát ${ }^{1}$, s ugyanakkor több teret engedni a kreativitásnak, az egyéni kezdeményezésnek, a kimagasló képességü tanulók speciális támogatásának. Ez a periódus azért is tekinthető külön periódusnak, mert ez az első korszak, amelyben japán szakemberek először vállalkoztak arra, hogy a tehetségpedagógia kérdéseiről explicit módon írjanak, illetve az első olyan periódus, amikor konkrét tehetségpedagógiai programokat indított meg az oktatásirányítás (ezekről a későbbiekben lesz még szó).

\section{A rendszerszintü stratégia és a jól tagolt tehetségpedagógiai struktúra hiánya}

Mindazonáltal az, hogy az oktatásirányítás kezdeményezte, sőt bátorította bizonyos tehetségpedagógiai lehetőségek létrehozását, az utóbbi évtizedek során sem jelentette azt, hogy rendszerszintű stratégiát és jól tagolt oktatási struktúrákat hoztak volna létre ezen a téren a japán oktatásügyben. Ennek hiányáról ugyancsak lényegében minden, a témával foglalkozó szakirodalmi mű szerzője megemlékezik (ld. pl. Sumida, 2013). Vagyis a mégis csak megvalósított tehetségpedagógiai rendszerelemek egyrészt fragmentált, némiképp izolált elemek lettek, maradtak a japán oktatásügy egészének rendszerében, másrészt mint arról ugyancsak szó lesz a későbbiekben - az oktatásirányítás akarva-akaratlanul is hozzájárult ahhoz, hogy a tehetséges tanulók speciális fejlesztése nem kis részben „kiszerveződjön" a formális oktatás rendszeréből, és áthelyeződjön a nem-formális oktatás képzési rendszerébe.

\footnotetext{
1 A japán oktatásügy kimagasló eredményességét az első PISA kutatásokat 3 évtizeddel megelőző nemzetközi oktatási mérések is már egyértelműen kimutatták. Ilyen volt például az IEA 1970-es First International Science Study címü kutatása is, amelynek során 18 ország közül a japán természettudományos oktatást találták a legeredményesebbnek mind az elemi iskolások, mind az alsó középiskolások körében (ld. pl. Sumida, 2013).
}

\section{Ami mégis van - és tehetségpedagógiai elemnek (is) tekinthetö a mai japán oktatásügyben}

Az, hogy a 2. világháborút követő Japánban nem volt, illetve nincs - csak néhány szórványos elemben müködik - de jure tehetségpedagógia, nem jelenti azt hogy de facto ez nem létezne mégis. Ugyanis ilyeneket egy oktatásügyben a rendszerelemek logikája, működésmódjának elve akkor is létrehozhat, ha azok az oktatáspolitikai intencióikat, illetve konkrét megnevezésüket tekintve nincsenek is ott. Nem véletlen, hogy a japán tehetséggondozás alapjellemzőit összefoglaló tanulmányában Matsumura (2016) virtuális vagy de facto tehetségpedagógiai rendszerről beszél a japán oktatásügy jelenével kapcsolatosan (West, 2016). A tanulmány most következő részében először az ilyen de facto tehetségpedagógiai rendszerelemek közül ismertetek néhányat, majd az utóbbi évek de jure is ilyenként felépített rendszerelemeiről szólok.

\section{A/ A de facto (quasi) tehetséggondozásnak (is) tekinthetö rendszerelemek a mai japán oktatásügyben}

A 2. világháború utáni japán oktatásügy de facto legfontosabb tehetségpedagógiai rendszerét az oktatás vertikális és horizontális szintjei közötti szelekciós mechanizmusok hozzák létre. A 2. világháború után Japánban a $6+3+3$ éves oktatási szerkezetet vezették be. Az elemi iskola 6 évét követően egy formális, komolyabb tét nélküli vizsga letételével kerülnek a tanulók az alsó középiskola 3 évébe, ennek lezárásakor azonban egy erősen szelektív vizsgával juthatnak csak át a felső középiskolába. Noha egy-egy életkori korosztály túlnyomó része, 97\%-a (West, 2016) átjut erre a képzési szintre is, de nem mindegy, hogy milyen iskolatípusba és mely iskolába. A legmagasabb presztízzsel természetesen az egyetemi továbbtanulásra felkészítő középiskolák rendelkeznek, amelyeket évről évre rangsorolnak a tanulóik felvételi eredményei alapján, és ezeket a rangsorokat nyilvánossá is teszik (Matsumura, 2016; West, 2016). Így mindenki tisztában van azzal, hogy melyek a legjobb, illetve a kevésbé jó felső kö- 
zépiskolai oktatási intézmények, és a tanulók ennek megfelelően nyújtják be a felvételi jelentkezéseiket. A szigorúan meritokratikus felvételi vizsgák alapján így egy-egy felső középiskolában mindig nagyjából homogén képességű diákok tanulnak, ami a képzés színvonalát tekintve legkiemelkedőbb intézmények esetében azt jelenti, hogy ezek quasi tehetséggondozó iskolák. Nem meglepő módon ezekből az iskolákból jutnak be legmagasabb számban a legjobb egyetemekre a tanulók - tehát az alsó középiskolából a felső középiskolába átvezető vizsgarendszer lényegében - de azért persze nem teljes egészében - a felsőoktatási tehetségszelekció funkcióját is betölti (Gordon Győri, 1998). Azt, hogy az iskolák rangsorolása, illetve ezek nyilvánossá tétele fontos érdeke a tanulóknak, illetve családjaiknak, mi sem mutatja jobban, mint az a tény, hogy 1967-től, amikor Tokióban eltörölték az iskolai rangsorrendszert, a tehetséges tanulók inkább a biztosan tudhatóan magas akadémikus színvonalú, fizetős magániskolákba jelentkeztek, ezzel mintegy akaratlanul is színvonalbeli esésre kárhoztatva a tokiói állami iskolákat. Amint több évtizedes kísérletezgetés után 2001-ben - Tokió felhagyott ezzel a politikával, ismét elkezdett emelkedni az állami iskolák színvonala is, az ismét oda jelentkező tehetséges tanulóknak (is) köszönhetően (West, 2016).

Hasonlóképpen tehetségpedagógiai funkciója van a japán iskolákban működtetett délutáni szakköröknek (Gordon Győri, 1998). Ezek választéka iskolánként változó lehet, de sport, harcművészet, zene, irodalom, kézművesség és hasonlók lényegében mindenütt szerepelnek a szakkori kínálat sorában. Nyilvánvaló, hogy egy-egy szakkörre a terület iránt érdeklődőbb, általában jobb képességekkel és teljesítményekkel rendelkező tanulók jelentkeznek: Tisztán tehetséggondozó rendszerelemnek azonban mégsem mondhatjuk ezt, minthogy általában minden tanulónak legalább egy szakkört kell vagy „illik” választania, így azok a diákok is felvesznek bizonyos szakköröket, akik az adott tantárgyban nem mutatkoznak tehetségesebbeknek, mint a társaik.

Ugyancsak nem tisztán tehetségpedagógiai rendszerelem a japán oktatásügyben az ár- nyékoktatás rendszere (Gordon Györi, 2008; Bray, 1999). A formális oktatást kiegészítő for-profit magánoktatásipar funkciójaként a szakirodalom két lehetőséget nevez meg mindenekelőtt: a korrepetáló és a tehetséggazdagító funkciót (Gordon Györi, 2006). Az árnyékoktatási ipar Japánban számos szervezeti formában és módszerrel működik, internetes képzéstől levelező formáig, egy-az-egyben oktatási formától a többszáz tanulós előadások keretében. E képzések nem kis részben az akadémikus területeken magas teljesítményü, tehát e téren tehetséges tanulók további fejlesztését, a legjobb egyetemekre való bejutásuk előkészítését szolgálja (Matsumura, 2016) - vagyis ugyancsak de facto tehetséggondozó oktatási formák -, még ha e tehetségpedagógiai tevékenység arányairól a japán árnyékoktatásipar egészének arányaiban nem rendelkezünk is megbízható adatokkal.

Hasonlóképp quasi tehetségpedagógiai rendszerelemnek tekinthetők a különféle nemzeti tudományos és matematikai versenyek, mint például a Science and Technology Contest, illetve az olyanféle, részben amerikai mintákra is szerveződő nyári táborok, mint például 1995-től kezdődően a Science Camp program, vagy 2008-tól a Next-Generation Scientist Program (Sumida, 2013). Ugyancsak a privát szektorban müködik és ugyancsak részben amerikai mintára a Children's Academy (Chan, 2018).

Ugyancsak qausi tehetségpedagógiai rendszerelemeknek nevezhetők a japán oktatás terén felbukkanó programokat, mint amilyen például a Suzuki módszer a hegedútanulásban. Bár a japán pedagógiai szakértők ezt a képzési módszert nagy valószínűséggel nem tehetségpedagógiai elveken, hanem éppen a „zene mindenkié" elveken épülő tömegképzési formának tekintenék a zeneoktatás terén, „nyugati” szemmel nézve a metódus kiválóan alkalmas a korai tehetségek fejlesztésére és azonosítására (is).

\section{$B / A$ de jure (forma szerint) is tehetséggondozó rendszerelemek a mai japán oktatásügyben}

Az 1990-es évekkel kezdődő tehetségpedagógiai paradigmaváltás mögött a japán kor- 
Van? Nincs? Hogyan van, ha nincs? Esszé a japán tehetségpedagógiáról

mányzatnak az az 1995-ben meg is fogalmazott felismerése állt, miszerint az ország technikai fejlődésének kulcsa a minél magasabb színvonalú tudományos és technológiai képzés (Sumida, 2013). Az oktatásügyi paradigmaváltás fontos határköve volt Japánban az Oktatási Minisztérium (MEXT, 1996 idézi: West, 2016) 1996-ban megfogalmazott hivatalos ajánlása, miszerint támogatni kell a matematikában és fizikában tehetségesnek mutatkozó tanulók egyéni képességeinek maximális kibontakoztatását az oktatásügyben, mert ez a tudományos technológiai versenyképesség jövőbeni megőrzésének és megerősítésének is a kulcsa Japánban.

E rendszerelemek közül mindenekelőtt a Super Science High Schoolokat érdemes megnevezni (Chan, 2018; West, 2016; Matsumura, 2016; Ibata-Arens, 2012). Ezek - természettudományos tehetségek speciális képzőintézményeiként - 2001 után kezdték meg a működésüket. Mára már több tucat müködik belölük Japánszerte (Matsumura, 2016), akárcsak a hasonló elveken működő speciális tehetséggondozó iskolák angol nyelvből (Chan, 2018). A kétféle területen működő tehetséggondozó iskolák léte jól mutatja, hogy Japán miben kíván erősödni: a globális piacverseny vezető pozícióinak megőrzéséhez, részben visszaszerzéséhez szükséges területeken, vagyis a természettudományokban és az angol nyelvben. Ugyanakkor e 3 éves felsőközépiskolákba, vagy a hasonló elven működő néhány 6 évfolyamos kombinált alsó- és felsőiskolába a japán tanulóknak csak egy nagyon kis töredéke jut be - úgyhogy ezek az iskolák igazi tudáselitképző intézményekként müködnek.

Ugyancsak a 2000-es évek fordulóján, 1997-ben a japán Oktatási Minisztérium ismét lehetővé tette az akceleráció egy formáját, a korai, 18 éves kor előtti egyetemkezdést, a 11. évfolyamra járó tanulóknak (West, 2016; Matsumura, 2016). (Azért ismét, mert az akceleráció lehetősége a két világháború között és kevéssel utána is létezett még, csak később eltörölték /Sumida, 2013/). Noha elöször ezt csak a matematikai képzés terén tették lehetővé, a rendszer bevezetését követően nem sokkal néhány más területet is megnyitottak a korai belépők számára, például az orvosegyetemi képzést.

\section{Tehetségpedagógia egalitárius országokban}

Mindent összevetve, és a tanulmányban eddig nem is említett további szempontokat is figyelembe véve, talán megengedhető szakmai vélekedés az, hogy a japán oktatásügy számára azért szinte megoldhatatlan kérdés a tehetséges gyerekek pedagógiája - azért van is, miközben nincs is -, mert ahhoz, hogy egyértelmüen lehessen vagy tényleg ne lehessen tehetségpedagógia a szigetország oktatásügyén belül, túl sok és túl mélyreható társadalmi, politikai, ideológiai, kulturális paradoxont kellene feloldania és megoldania a társadalomnak, illetőleg a szakembereknek. A tanulmány zárásaképp ezek közül foglalok össze néhányat.

A japán tehetségpedagógiát lényegében megoldhatatlan dilemmák elé állító látszólagos vagy valós dilemmák egyike például a képességekbe és erőfeszítésbe vetett hit japán mintázata. Mint az 1970-es évek óta számos nyugati kutató is leírta (ld. pl. Gordon Györi, 2006) japánban az emberek az európai és amerikai személyekhez képest tendenciaszerüen erősebben hisznek abban, hogy az ember teljesítményét az erőfeszítés mértéke és minősége sokkal inkább meghatározza, mint a képességei (Heuser et al, 2017; Sumida, 2013; Ibata-Arens, 2012; Gordon Györi, 2006). Ha azonban ez így van, akkor valójában ugyanazok az oktatási feltételek megfelelőek mindenkinek, és változtatásokra sokkal inkább a kevésbé jól teljesítő tanulók attitűdjében van szükség, semmint az oktatás strukturális elemeinek átrendezésében, amelyek például egyenlőtlenségekhez vezethetnek az oktatásban. Matsumura (2016) úgy vélekedik, hogy a tehetségpedagógia azért sem tud továbbra sem kibontakozni Japánban, mert az általános közvélemény mélyen egyenlőségelvű alapokon továbbra is erősen ellenzi a speciális képzések érdekében történő tanulói szelekciós eljárásokat. 
Egy következő ilyen - más egalitárius eszméken nyugvó társadalmak számára is szinte feloldhatatlan - dilemmát jelent az egalitárius eszmék kontra gazdasági, geopolitikai, geokatonapolitikai stb. érdekek felől nézett tehetségpedagógiai szükségletek kettőse (Szegal, 1989; Gordon Györi, 2016). Míg ezen a téren a társadalmi egyenlőségeken nyugvó harmóniát preferáló politikusok és oktatáspolitikusok ellenzik a tehetségpedagógiai lehetőségeket, akár ugyanezen politikusok és szakemberek is, de az ellenzéküket jelentő csoportokba tartozók is a társadalmi, technikai, katonapolitikai és egyéb okokból szükséges tudáselitizmus mint a fejlődést biztosító elkerülhetetlen rendszerelemek mellett érvelnek az oktatásban. A Szovjetunió, Kína, vagy akár a gazdasági válságokat a 2000-es évek elején átélő észak-európai szociáldemokrata tradíciójú országok példája is azt mutatja, hogy az egyenlőségelvű ideológiákat előtérbe helyező társadalmakban rendre felerősödik az a nézet, miszerint a társadalmi egyensúlyok megbontásának veszélyei ellenére is elkerülhetetlen a tudáselit- (tehát tehetség-)pedagógia bevezetése az oktatási rendszerükbe, mert különben nem nevelődnek ki a nemzetközi versenyképességgel is bíró társadalmi és gazdasági csoportjaik, lemaradnak a nemzetközi gazdasági és egyéb versenyben. Japánhoz nagyon is hasonlóan, a finn oktatásban is kimutatható a tehetségpedagógiai rendszerelemek jelenléte, noha éppúgy mint Japánban, ezekre Finnországban sem mint egyértelműen tehetségpedagógiai elemekre tekintenek (Heuser et al, 2017; Tirri E Kuusisto, 2013).

Mindazonáltal jól megfigyelhető, hogy a japán oktatásügyben és a társadalomban mint számos más társadalom oktatásügyében is - évtizedek óta kétféle egyenlőségfogalom küzd egymással: az azonosság, vagyis az abszolút egyenlőség elve, illetőleg a relatív, vagyis az arányos egyenlőség elve.

Shindo és munkatársai (Shindo et al, idézi West, 2016) kétféle egyenlőségről beszélnek az oktatás terén: az egyiket formális egyenlőségnek nevezik, amelyben mindenki azonos módon ugyanazt a képzést kapja, függetlenül az éppen aktuális fejlődési kapacitásaitól, tanulási sebességétől, a tanulási teljesítménye minőségétől vagy hasonlóktól. A másik fajta egyenlőséget lényegi egyenlőségnek, meritokratikus elveken alapuló egyenlőségnek nevezik, aminek a lényege, hogy - a vigotszkiji optimális tanulási zóna elméletnek megfelelően - minden tanuló a neki a fejlődésben éppen leghasznosabb mélységü, tempójú, jellegű képzésben részesül. Ez utóbbit az arányos egyenlőség elvének is nevezhetjük. E kétféle egyenlőségelv küzdelme azért sem zárult le évtizedek, sőt tulajdonképpen a tömegoktatás kialakulása óta sem Japánban, sem a világ számos más oktatási rendszerében, mert valójában mindkét megközelítés egyértelműen valid érvekkel támasztható alá, még ha ezek különféle - egyéni, csoportos, társadalmi vagy nemzetközi - aspektusokra épülő érvek is.

Tovább bonyolítja az oktatási egyenlőségelv társadalmi egyensúlyba hozásának lehetőségét az a tény, hogy a fent említett szereplők mindegyike egymásnak - látszólag vagy valóban - ellentmondó, alkalmasint egymást kizárónak gondolható érdekekkel rendelkezik önmagában is, még akkor is, ha ezeket a benső ellentmondásokat nem ismerik föl és így nem tudják megfelelően artikulálni sem. A legkézenfekvőbb példa erre a japán szülők példája, akik adott esetben akár a tömegmédiában vagy az utcán protestálnak és tüntetéseket is szerveznek az oktatási egyenlőség vívmányainak megőrzése, terjesztése és fejlesztése érdekében a formális oktatás keretein belül, miközben a saját gyermekeiket nagy pénzekért járatják az árnyékoktatási, nem-formális képzési intézményekbe is, ezzel egyértelmüen gyermekeik speciális oktatási előnyeit támogatva, tehát a társadalmi egyenlőtlenséget mozdítva előre.

A formális és a nem-formális oktatási rendszerelemek egymástól különböző müködéselvei egyben arra is rávilágítanak, hogy az egyes oktatási rendszerekben mindig egy sor olyan rendszerelem bukkan fel és müködik akár nagy hatással is rövidebb-hosszabb távon, amelyek az oktatáspolitikusok vagy akár a társadalom szélesebb rétegeinek explicit szándékaitól függetlenek, vagy kisebb-na- 
gyobb csoportok szándékaival ugyan egybe csengenek, de az oktatáspolitika hallgatólagos beleegyezéssel vagy éppen tehetetlensége miatt meghagyja ezeket, nem tudja és/vagy nem is akarja megszüntetni ezeket. Így jöhetnek létre olyanféle quasi rendszerelemek egyegy oktatásügyben, mint amilyen a mai japán oktatásban a tehetségpedagógiai rendszerelemek többsége, mint ahogy az látható az eddig leírtakból.

A japán példa számos tanulsággal szolgál. Rámutat arra, milyen bonyolult, ellentmondásos a helyzete a tehetséges gyerekek pedagógiájának azokban az egyenlőségelvü társadalmakban, amelyekben az egyenlőséget mint azonosságot fogják fel az oktatásügyben és a hétköznapi emberek is a társadalomban. Ellentmondásos helyzetek alakulnak ki, mert az uralkodó ideológiával szemben vagy attól bizonyos mértékben függetlenül a társadalomnak és az oktatásügynek mégis csak válaszokat kell adnia, megoldásokat kell találnia a tehetséges gyerekek fejlesztésének kérdéseire. Japánban az oktatásügy egyrészt mai napig is elutasítja a tehetséggondozás szélesebb körben való elterjesztését, másrészt néhány kisebb rendszerelem keretében de jure mégis csak lehetővé teszi ezek működését, harmadrészt ha nem bátorítja is, de nem is teszi lehetetlenné olyanféle programok müködtetését, amelyek de facto a tehetséggondozást szolgálják a formális oktatásban, végül az oktatásirányítás nem akarja, mert jórészt nem is tudja befolyásolni a formális oktatási rendszeren kívül kialakuló és működő forprofit vagy másféle oktatási formákat, amelyek részben vagy egészükben a tehetséges tanulók speciális fejlesztését szolgálják.

Mindazonáltal az oktatásirányításnak más lehetőségei is vannak a tehetségpedagógia terén az egyenlőségelvű társadalmakban. Japánban például az oktatásirányítás explicit vagy implicit eszközökkel sem korlátozza az iskolai képzések színvonalát annak felső szegmenseit tekintve, vagyis a tehetséges tanulók számára kijelölt tananyag mennyisége, mélysége, minősége az iskolák szabad döntésének függvénye. Egy ilyen helyzetben valóban megkérdőjelezhető, hogy szükség van-e szegregált, elkülönülő tehetségpedagógiai alrendszerekre.

Ugyancsak elejét veszi az elitista oktatási viták egy részének az, ha a tehetségpedagógia tevékenységelemei a nemzeti humánerőforrás-fejlesztés részeként jelennek meg, és így is artikulálódnak a szakmai és a tömegkommunikációs csatornákon. A humánerőforrás-fejlesztési paradigma mint a tehetségfejlesztési paradigma alternatívája ${ }^{2}$ nemcsak Japánban, hanem általában is erős a kelet-ázsiai, konfuciánus hagyományokkal rendelkező, kollektivista társadalmakban (Chan, 2018), mint például Kínában, Szingapúrban, Dél-Koreában, Vietnamban és másutt, ami arra mutat, hogy az egyes társadalmakban, oktatási rendszerekben a kulturális kontextus is mélyen befolyásolja a tehetséges tanulók pedagógiájának lehetséges formáit.

Végül: mint a kultúra és a társadalmi élet sok más elemében, Japán a tehetséggondozás terén is képes volt egy olyan, az euro-amerikai hagyományok felől nézve nehezen értelmezhető konstrukciót létrehozni a 20-21. századi pedagógiai gyakorlatában, amely hatékonyan működik, mégis, a nyugati szemlélők számára lényegében feloldhatatlan paradoxonokként jelenik meg. Jelen tanulmány azt mutattam be, hogyan működik a japán tehetségpedagógia, amely nincs. Márpedig a hatékonysága mára már valóban kétségbevonhatatlan, hiszen most már nemcsak a PISA- és a TIMSSkutatások sora mutatja évtizedek óta a japán oktatás figyelemre méltó hatékonyságát a legfelsőbb képesség- és teljesítményszintű, tehát a tehetséges tanulók esetében is, hanem Japán továbbra is töretlen gazdasági sikerei a csúcstechnológia terén, vagy például a japán Nobel-díjasok évről évre emelkedő száma.

2 A humánerőforrás-fejlesztési paradigmában (Chan, 2018; Gordon-Györi, 2016) erősebben hangsúlyozódnak a nemzeti, össztársadalmi érdekek és értékek a tehetségpedagógiai erőfeszítések célrendszerében, míg a tehetségfejlesztési paradigmában hangsúlyosabban artikulálódnak az egyéni és kisközösségi (családi stb.) érdekek és értékek a tehetségfejlesztés és tehetségaktualizáció terén, harmóniában vagy diszharmóniában az össztársadalmi, nemzeti érdekekkel. 


\section{Felhasznált irodalom}

Bray, M. (1999): The shadow education system: Private tutoring and its implications for planning. UNESCO.

Chan, D. W. (2018): Gifted education in Asia. In: Pfeiffer, S. I. (ed.) APA Handbook of giftedness and talent. American Psychological Association, Washington DC, 71-84. https://doi.org/10.1037/0000038-005

Gordon Gyõri János (1998): Mitõl hatékony még a japán oktatás: A hivatalos oktatási rendszer tanítási óráin kívüli képzés és oktatás Japánban. Magyar Pedagógia, 98. 4. sz., 273-317.

Gordon Győri János (2006): Az oktatás világa Kelet- és Délkelet-Ázsiában: Japán és Szingapúr. Gondolat Kiadó, Budapest.

Gordon Győri János (2008): Tömegoktatás és kiegészítő magánoktatás-ipar. Educatio, 17. 2. sz., 263-274.

Gordon Győri János (2016): Humánerőforrásfejlesztés a gyors társadalmi és gazdasági fejlődés szolgálatában: Jó gyakorlat a kínai tehetséggondozásban. In: Gordon Győri János (szerk.) A tehetséggondozás világa: 15 ország jó gyakorlata a tehetséggondozásban.Család-, Ifjúság- és Népességpolitikai Intézet, Budapest.

Heuser, B. L., Wang, K. \& Shahid, S. (2017): Global dimensions of gifted and talented education: The influence of national perceptions on policies and practices. Global Education Review, 4. 1. sz., 4-21.

Ibata-Arens, K. C. (2012): Race to the future: Innovation in gifted and enrichment education in Asia, and implications for the United States. Administrative Sciences, 2, 1-25. https://doi.org/10.3390/admsci2010001

Matsumura, N. (2016): Virtual gifted education in Japan. In: Dai, D. Y.\& Kuo, C. C. (eds.) Gifted education in Asia: Problems and prospects. Information Age Publishing, Charlotte, 121-146.

MEXT. (1996): Chuuou Kyouiku Shingikai dai-2 Shou-iinkai Dai-14-kai Giji Youshi (Minutes of the 14th Central Educational Council Second Subcommittee Meeting). Ministry of Education, Culture, Sports, Science and Technology, Japan. http://www.mext.go.jp/b_ menu/shingi/old_chukyo/old_chukyo_index/ bun kabukai/bukaiiinkai/gijïroku/1309245. htm

Shindo, A., Koba, H., Hasegawa, H. \& Ogura, Y. (2009): Korekara no Sainou Kyouiku no Houkousei. (Direction of the Talent Education from Now.) In Rika Kyouiku Shien Center Rika Kyouiku Shien Kentou Task Force Sainou Kyouiku Bunkakai Kaigi Shiryou. (In: Science Education Support Center Science Education Support Research Taskforce Gifted Education Subcommittee Meeting Material) http://www. jst.go.jp/cpse/risushien/highschool/vol1/1_4. pdf

Sumida, M. (2013): Emerging trends in Japan in education of the gifted: A focus on science education. Journal for the Education of the Gifted, 36. 3. sz., 277-289.

https://doi.org/10.1177/0162353213493534

Szegal Borisz (1989): A tehetséges gyermekek a Szovjetunióban: Elméletek, felfogások, álláspontok, kutatás és gyakorlat. In: Ranschburg Jenő (szerk.) Tehetséggondozás az iskolában. Tankönyvkiadó, Budapest, 283-312.

Tirri, K. \& Kuusisto, E. (2013): How Finland serves gifted and talented pupils. Journal for the Education of the Gifted, 36, 84-96. https://doi.org/10.1177/0162353212468066

West, K. I. (2016): Gifted education in Japan. In B.R. Vogeli (Ed.), Special secondary schools for the mathematically talented: An international panorama. World Scientific, New Jersey, 171-184. 


\section{Does it exist or not? How does it exist if it doesn't exist? An essay on gifted education in Japan}

This essay introduces Japan as a very competitive and equalist society at the same time - at least in the field of formal main stream education. Even the expression itself („gifted") could be hardly find in Japanese. Because of a number of traditional cultural values and contemporary ideologies in education, many educational policy makers and other members of the societyteachers, students, parents and others - are ambivalent with gifted education. Anyway there is a number of programs in Japanese education which we can take as programs for the gifted students. This article introduces and analises the conceptual background and everyday practice of Japanese gifted education.

Keywords: equalism in education, gifted education, Japan

Gordon Győri János (2019): Van? Nincs? Hogyan van, ha nincs? Esszé a japán tehetségpedagógiáról. Gyermeknevelés, 7. 1. sz., 12-21. 